\title{
TOPOGRAPHY AND SPATIAL VARIABILITY OF SOIL PHYSICAL PROPERTIES
}

\author{
Marcos Bacis Ceddia ${ }^{1 *}$; Sidney Rosa Vieira²; André Luis Oliveira Villela ${ }^{3}$; Lenilson dos \\ Santos Mota ${ }^{5}$; Lúcia Helena Cunha dos Anjos ${ }^{1}$; Daniel Fonseca de Carvalho ${ }^{4}$ \\ ${ }^{1}$ UFRRJ - Depto. de Solos, BR 465 - km 7 - 23900-000 - Seropédica, RJ - Brasil. \\ ${ }^{2}$ IAC - Centro de Solos e Recursos Ambientais, C.P. 28 - 13020-902 - Campinas, SP - Brasil. \\ ${ }^{3}$ UFRRJ - Programa de Pós-Graduação em Agronomia-Ciência do Solo. \\ ${ }_{5}^{4} U F R R J$ - Depto. de Engenharia - BR 465 - km 7 - 23900-000 - Seropédica, RJ - Brasil. \\ ${ }^{5}$ UFRRJ - Graduando em Engenharia Agronômica. \\ *Corresponding author <ceddia@ufrrj.br>
}

\begin{abstract}
Among the soil formation factors, relief is one of the most used in soil mapping, because of its strong correlation with the spatial variability of soil attributes over a landscape. In this study the relationship between topography and the spatial variability of some soil physical properties was evaluated. The study site, a pasture with 2.84 ha, is located near Seropédica, Rio de Janeiro State, Brazil, where a regular square grid with $20 \mathrm{~m}$ spacing was laid out and georreferenced. In each sampling point, altitude was measured and undisturbed soil samples were collected, at 0.0 $0.1,0.1-0.2$, and $0.2-0.3 \mathrm{~m}$ depths. Organic carbon content, soil texture, bulk density, particle density, and soil water retention at 10 (Field Capacity), 80 (limit of tensiometer reading) and $1500 \mathrm{kPa}$ (Permanent Wilting Point) were determined. Descriptive statistics was used to evaluate central tendency and dispersion parameters of the data. Semivariograms and cross semivariograms were calculated to evaluate the spatial variability of elevation and soil physical attributes, as well as, the relation between elevation and soil physical attributes. Except for silt fraction content (at the three depths), bulk density (at $0.2-0.3 \mathrm{~m}$ ) and particle density (at $0.0-0.1 \mathrm{~m}$ depth), all soil attributes showed a strong spatial dependence. Areas with higher elevation presented higher values of clay content, as well as soil water retention at 10,80 and $1500 \mathrm{kPa}$. The correlation between altitude and soil physical attributes decreased as soil depth increased. The cross semivariograms demonstrated the viability in using altitude as an auxiliary variable to improve the interpolation of sand and clay contents at the depth of $0.0-0.3 \mathrm{~m}$, and of water retention at 10,80 and $1500 \mathrm{kPa}$ at the depth of $0.0-0.2 \mathrm{~m}$.
\end{abstract}

Key words: terrain elevation, geostatistics, soil physics, cross semivariance

\section{TOPOGRAFIA E VARIABILIDADE ESPACIAL DE PROPRIEDADES FÍSICAS DO SOLO}

RESUMO: O relevo é um dos fatores de formação do solo mais usados em mapeamento de solos devido sua forte correlação com a variabilidade espacial de atributos do solo na paisagem. O objetivo desse trabalho foi avaliar a relação entre topografia e a variabilidade espacial de algumas propriedades físicas de solos. Em uma pastagem com 2,84 ha instalou-se uma grade regular com espaçamento de 20 $\mathrm{m}$, nas proximidades de Seropédica, RJ, onde cada ponto de amostragem foi georreferenciado. Em cada ponto de amostragem foi medida a altitude e foram coletadas amostras indeformadas nas profundidades de $0,0-0,1 ; 0,1-0,2$ e $0,2-0,3 \mathrm{~m}$. Determinaram-se os teores de carbono, textura, densidade do solo e das partículas e retenção de água a 10,80 e $1500 \mathrm{kPa}$. Estatística descritiva foi usada para avaliar a tendência central e a dispersão dos dados. Semivariogramas simples e cruzados foram usados para avaliar a variabilidade espacial da altitude, e dos atributos físicos do solo, bem como a relação entre altitude e atributos físicos do solo. Com exceção da fração silte (nas três profundidades), densidade do solo $(0,2-0,3 \mathrm{~m})$ e densidade das partículas $(0,0-0,1 \mathrm{~m})$, todos os atributos apresentaram forte dependência espacial. Encontraram-se maiores teores de argila, bem como de retenção de água a 10, 80 e $1500 \mathrm{kPa}$, nas cotas mais elevadas. A correlação entre altitude e atributos físicos decresceu com o aumento da profundidade. Os semivariogramas cruzados comprovaram a viabilidade do uso da altitude, por cokrigagem, para aperfeiçoar a interpolação de areia e argila na camada de $0.0-0.3 \mathrm{~m}$, e de retenção de água a 10,80 e $1500 \mathrm{kPa}$ na camada de $0.0-0.2 \mathrm{~m}$.

Palavra chave: elevação do terreno, geoestatística, física do solo, semivariograma cruzado 


\section{INTRODUCTION}

Soil sampling allows the characterization of several soil attributes which may be estimated at unsampled sites through existing models. Deterministic models are considered to be more appropriate when there is enough information on physical and chemical properties, and allow the understanding of the phenomenon as a whole (Isaaks \& Srivastava, 1989). However, very few processes are understood enough to allow the use of such models.

The use of deterministic models for the understanding of both soil formation and their attributes does not result in accurate estimation, because of the great complexity among soil properties (Webster, 2000). Probabilistic models admit some uncertainty about how the phenomenon succeeds, and available data are considered as results of a random process (Isaaks \& Srivastava, 1989). The geostatistics focus is based on a probabilistic model, and has been successfully used in soil science for a quantitative description of spatial variability, which may support predictions about the phenomena investigated (Vieira, 2000).

The identification of landscape features is an important tool used by pedologists in their soils mapping procedures. The use of landscape elevation digital models has increased predictions on soil parameters from terrain attributes. Since topography parameters, defined from primary and secondary attributes, controls water and sediments distribution over the landscape, researchers have been trying to correlate landscape features (altitude, slope, shape) with physical soil attributes (Kreznor et al., 1989; Pachepsky et al., 2001; Sobieraj et al., 2002; Rezaei \& Gilkes, 2005). Spatial variability of soil color and texture were considered feasible to be used in models of digital soil mapping in Southern of Amazon (Novaes Filho et al., 2007). Many authors also evidenced the influences of landforms on soil physical properties. Working with soils of northeastearn of Sao Paulo State, Souza et al. (2004) found that small variations in the landscape form defined different spatial variability in soil physical attributes. Similar results were found by Souza et al. (2003), which evaluate the effect of landforms on anisotropy of soil physical attributes and observed higher spatial variability of soil physical attributes in the concave landform when compared to the linear one.

Considering the importance of mapping spatial variability of soil physical attributes and its relation with relief, the objective of this study was to evaluate the relationship between topography and the spatial variability of some soil physical properties in a hillside area used as a pasture.

\section{MATERIAL AND METHODS}

\section{Semivariograms}

The experimental semivariogram, $\gamma(h)$, of $n$ spatial observations $\mathrm{z}\left(\mathrm{x}_{\mathrm{i}}\right), \mathrm{i}=1, \ldots \mathrm{n}$, can be calculated using

$$
\gamma(\mathrm{h})=\frac{1}{2 \mathrm{~N}(\mathrm{~h})} \sum_{\mathrm{i}=1}^{\mathrm{N}(\mathrm{h})}\left[\mathrm{Z}\left(\mathrm{x}_{\mathrm{i}}\right)-\mathrm{Z}\left(\mathrm{x}_{\mathrm{i}}+\mathrm{h}\right)\right]^{2}
$$

where $\mathrm{N}(\mathrm{h})$ is the number of observations separated by a distance $h$. Experimental semivariograms can be fit in to a variety of models that have well known parameters: nugget $\mathrm{C}_{0}$, sill $\left(\mathrm{C}_{0}+\mathrm{C}_{1}\right)$, and range of spatial dependence (a), McBratney \& Webster (1986). Equation (1) is obtained from a derivation starting at the intrinsic hypothesis, under which there is no requirement for existence of a finite variance of the observations, $\operatorname{Var}(\mathrm{z})$. Only stationarity of the differences $\left[\left(Z\left(x_{i}\right)-Z\left(x_{i}+h\right)\right]\right.$ are required for its derivation (Journel \& Huijbregts, 1978).

\section{Scaled semivariograms}

The scaling technique of semivariograms was developed by Vieira et al. (1997) and expressed as:

$\gamma_{\mathrm{i}}^{\mathrm{sc}}(\mathrm{h})=\frac{\gamma_{\mathrm{i}}(\mathrm{h})}{\alpha_{\mathrm{i}}} \quad \mathrm{i}=1,2, \ldots, \mathrm{m}$

where $\gamma^{s c}(h)$ is the scaled semivariogram, $\gamma(\mathrm{h})$ the original semivariogram, $\alpha_{i}$ is the scale factor and $\mathrm{m}$ is the number of measured variables. The scale factor $\alpha$ is a constant that can take the value of the calculated variance - the sill when it exists - or the highest value of the semivariogram $\gamma(\mathrm{h})$. The idea is that if semivariograms of properties sampled over the same field scale together on the same graph then their spatial variabilities can be related to common causes.

\section{Cross-semivariogram}

It is possible that spatial dependence between two variables exists and it may be used in the estimation of one of them using both of them using cokriging. Vauclin et al. (1983) used cokriging and observed that there was a decrease in the cokriging estimation variances as compared to the kriging. Spatial dependence between two variables $Z_{1}$ and $Z_{2}$ can be expressed by the cross semivariogram

$$
\gamma_{12}(h)=\frac{1}{2 N(h)} \sum_{i=1}^{N(h)}\left[Z_{1}\left(x_{1 i}+h\right)-Z_{1}\left(x_{1 i}\right)\right]\left[Z_{2}\left(x_{2 j}+h\right)-Z_{2}\left(x_{2 j}\right)\right]
$$

The cross semivariogram is subject to the same hypothesis as the semivariogram and can be fit to the same model equations. The basic difference is that the cross semivariogram can be negative if one 
variable changes in the opposite direction as the other. Cokriging development can be found elsewhere (Goovaerts, 1997; Vieira, 2000).

\section{Study site and sampling procedures}

The study site has 2.84 ha and is located between $43^{\circ} 40^{\prime}$ and $43^{\circ} 41^{\prime} \mathrm{W}$, and $22^{\circ} 44^{\prime}$ and $22^{\circ} 45^{\prime}$ $\mathrm{S}$, in the Seropédica municipality, Rio de Janeiro State, Southeastern region of Brazil. The area has pasture coverage implanted in 1997 and was formed exclusively by the Transvala grass (Digitaria decumbens Stent cv Transvala).

In order to apply geostatistics to investigate the spatial variability of soil physical attributes, the sampling strategy included the definition of a $20 \mathrm{~m}$ spacing square grid. Since spacing between sampling points might affect data modeling, additional soil samples were collected in a reduced spacing $(1,5$ and $10 \mathrm{~m})$, according to topography and soil classes, as recommended by Trangmar et al. (1985). In each of the 89 sampling points, altitude and UTM coordinates were measured using a GPS with differential correction (DGPS - Trimble-GeoExplorer 3 model), with submetric accuracy.

\section{Soil chemical and physical analysis}

Undisturbed soil samples were collected at depths of $0.0-0.1,0.1-0.2$ and $0.2-0.3 \mathrm{~m}$, for the determination of water retention at 10 (field capacity), 80 (limit of a tensiometer reading), $1,500 \mathrm{kPa}$ (permanent wilting point) and soil bulk density - $\rho_{\mathrm{b}}$ (doublecylinder method) (Embrapa, 1997). Readily available water capacity $(\mathrm{EAWC}=10 \mathrm{kPa}-80 \mathrm{kPa})$ and available water capacity $(\mathrm{AWC}=10 \mathrm{kPa}-1,500 \mathrm{kPa})$ indices were calculated from the water retention data. Loose soil samples were grinded and air-dried for determination of: soil particle density - $\rho_{\mathrm{s}}$ (volume determination method), soil particle size distribution (Pipette method) (Embrapa, 1997) and organic carbon content (Walkley \& Black, 1934).

\section{Statistical analysis}

Descriptive and exploratory analysis was performed to find both the central tendency and dispersion of data. BioEstat 2.0 (Ayres et al., 2003) and XLSTAT 7.5 (Addinsoft, 2004) softwares were used to evaluate the existence of outliers, as well as to perform both normality and Pearson correlation tests. Geostat (Vieira et al., 1983) software was used both to determine measures of spatial continuity (experimental semivariograms) and for model fitting to the semivariogram to be further used in the interpolation. The selection of the most proper model was done by cross-validation (jack knifing).

\section{RESULTS AND DISCUSSION}

\section{Descriptive analysis}

The descriptive statistical results for altitude and soil physical attributes are in Table 1. Samples were collected along a slope, with altitude values ranging from 26.2 to 33.7 meters above the sea level. The soil map unities (Figure 1) identified in the area were: PVD6 Loamy over fine clayey Kandiudult; PLD2 - Paleudult; and PLD3 - association of Paleudults + Aquents (Soil Survey Staff, 1999). The Paleudults with sandy over loamy texture were more common (74.3\%), and were preferentially found on the mid-slope and on the foot slope. Loamy over fine clayey Kandiudult were the dominant soil class on the hill tops $(25.7 \%)$.

Due to the greater occurrence of sandy over loamy Paleudults, and the sampling restricted to the upper $0.3 \mathrm{~m}$, the dominant class of texture at the three sampled depths was sandy, and it greatly influenced the other soil attributes, resulting in low water retention and availability. The sandy texture also influenced the bulk density values, which were considered to be relatively high (averaging 1.51-1.61 $\mathrm{kg} \mathrm{dm}^{-3}$ ), as well as soil particle density for the three depths (averaging $2.55-2.57 \mathrm{~kg} \mathrm{dm}^{-3}$ ). Those soil particle density values result from the dominance of the quartz mineral in the sand fraction (Silva et al., 2001).

The contents of sand, silt and clay were found to be quite similar at the $0.0-0.1 \mathrm{~m}$, and $0.1-0.2 \mathrm{~m}$ depths. At the $0.2-0.3 \mathrm{~m}$ depth data showed a greater variance, despite the average value being very similar
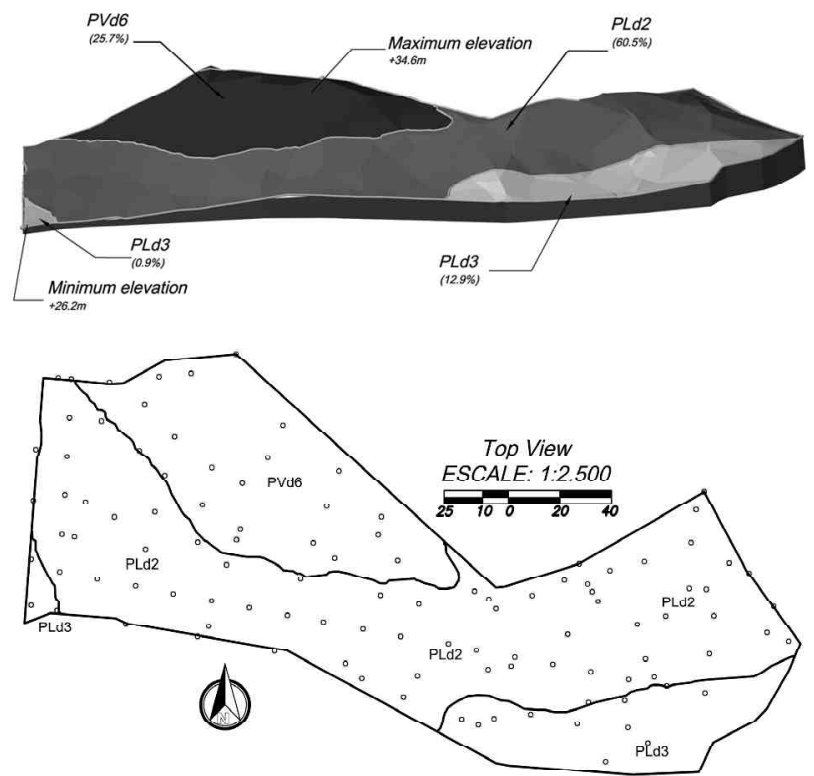

Figure 1 - Digital elevation model and location of sampling points in the study area, in Seropédica, Rio de Janeiro State, Brazil. PVD6 - Medium over fine clayey Kandiudult; PLD2 - Paleudult; PLD3 - Paleudults + Aquents. 
Table 1 - Summary of statistic values for altitude and soil attributes.

\begin{tabular}{|c|c|c|c|c|c|c|c|c|}
\hline Attributes & Minimum & Maximum & Mean & Median & Variance & C.V. & Skewness & $\mathrm{D}$ \\
\hline \multicolumn{9}{|c|}{ Soil depth $0.0-0.1 \mathrm{~m}$} \\
\hline Altitude (m) & 26.2 & 33.5 & 29.7 & 29.5 & 2.524 & 5.4 & 0.2937 & $0.0755 \mathrm{n}$ \\
\hline Carbon $\left(\mathrm{g} \mathrm{kg}^{-1}\right)$ & 4.7 & 32.3 & 16.0 & 16.4 & 37.7 & 38.6 & -0.0500 & $0.1002 \mathrm{n}$ \\
\hline $10 \mathrm{kPa}\left(\mathrm{cm}^{3} \mathrm{~cm}^{-3}\right)$ & 4.1 & 20.0 & 9.8 & 9.0 & 12.67 & 36.4 & 0.5152 & $0.0921 \mathrm{n}$ \\
\hline $80 \mathrm{kPa}\left(\mathrm{cm}^{3} \mathrm{~cm}^{-3}\right)$ & 2.4 & 15.6 & 7.0 & 6.4 & 9.792 & 44.7 & 0.7936 & $0.1179 \ln$ \\
\hline $1500 \mathrm{kPa}\left(\mathrm{cm}^{3} \mathrm{~cm}^{-3}\right)$ & 1.9 & 11.7 & 5.8 & 5.1 & 6.932 & 45.6 & 0.6783 & $0.1070 \ln$ \\
\hline EAWC $\left(\mathrm{cm}^{3} \mathrm{~cm}^{-3}\right)$ & 0.1 & 6.0 & 2.8 & 2.7 & 1.805 & 48.5 & 0.2132 & $0.0822 \mathrm{n}$ \\
\hline AWC $\left(\mathrm{cm}^{3} \mathrm{~cm}^{-3}\right)$ & 1.2 & 8.4 & 4.0 & 3.6 & 2.522 & 39.8 & 0.7266 & $0.1392 \ln$ \\
\hline$\rho_{\mathrm{b}}\left(\mathrm{kg} \mathrm{dm}^{-3}\right)$ & 1.29 & 1.73 & 1.51 & 1.53 & $9.03 \mathrm{E}-03$ & 6.3 & -0.1369 & $0.1001 \mathrm{n}$ \\
\hline$\rho_{\mathrm{s}}\left(\mathrm{kg} \mathrm{dm}^{-3}\right)$ & 2.26 & 2.85 & 2.55 & 2.56 & $1.13 \mathrm{E}-02$ & 4.2 & $-1.42 \mathrm{E}-02$ & $0.1457 \mathrm{n}$ \\
\hline Sand $\left(\mathrm{g} \mathrm{kg}^{-1}\right)$ & 740 & 970 & 884 & 900 & 30.11 & 6.2 & -0.8256 & $0.1617 \ln$ \\
\hline Silt $\left(\mathrm{g} \mathrm{kg}^{-1}\right)$ & 10 & 110 & 54 & 50 & 6.404 & 47.2 & 0.2102 & $0.1258 \mathrm{n}$ \\
\hline Clay $\left(\mathrm{g} \mathrm{kg}^{-1}\right)$ & 10 & 180 & 62 & 50 & 17.83 & 64.1 & 1.022 & $0.1821 \mathrm{ln}$ \\
\hline \multicolumn{9}{|c|}{ Soil depth $0.1-0.2 \mathrm{~m}$} \\
\hline Carbon $\left(\mathrm{g} \mathrm{kg}^{-1}\right)$ & 1.5 & 29.6 & 10.4 & 9.7 & 39.93 & 60.9 & 0.643 & $0.1430 \ln$ \\
\hline $10 \mathrm{kPa}\left(\mathrm{cm}^{3} \mathrm{~cm}^{-3}\right)$ & 3.6 & 15.5 & 8.1 & 8.0 & 9.119 & 37.1 & 0.4741 & $0.0882 \mathrm{n}$ \\
\hline $80 \mathrm{kPa}\left(\mathrm{cm}^{3} \mathrm{~cm}^{-3}\right)$ & 1.5 & 12.4 & 5.3 & 4.8 & 7.37 & 51.4 & 0.7732 & $0.1135 \ln$ \\
\hline $1500 \mathrm{kPa}\left(\mathrm{cm}^{3} \mathrm{~cm}^{-3}\right)$ & 0.8 & 9.1 & 4.1 & 3.7 & 5.073 & 54.8 & 0.7157 & $0.1507 \ln$ \\
\hline EAWC $\left(\mathrm{cm}^{3} \mathrm{~cm}^{-3}\right)$ & 0.5 & 8.8 & 2.9 & 2.7 & 1.889 & 48.0 & 1.195 & $0.0985 \ln$ \\
\hline AWC $\left(\mathrm{cm}^{3} \mathrm{~cm}^{-3}\right)$ & 1.6 & 9.2 & 4.0 & 4.1 & 1.676 & 32.1 & 0.8075 & $0.1057 \ln$ \\
\hline$\rho_{\mathrm{b}}\left(\mathrm{kg} \mathrm{dm}^{-3}\right)$ & 1.41 & 1.80 & 1.61 & 1.61 & $6.80 \mathrm{E}-03$ & 5.1 & $-5.46 \mathrm{E}-02$ & $0.0846 \mathrm{n}$ \\
\hline$\rho_{\mathrm{s}}\left(\mathrm{kg} \mathrm{dm}^{-3}\right)$ & 2 & 2.94 & 2.55 & 2.56 & 2.89E-02 & 6.7 & -0.2374 & $0.1153 \mathrm{n}$ \\
\hline Sand $\left(\mathrm{g} \mathrm{kg}^{-1}\right)$ & 710 & 960 & 883 & 900 & 36.38 & 6.8 & -1.175 & $0.1922 \ln$ \\
\hline Silt $\left(\mathrm{g} \mathrm{kg}^{-1}\right)$ & 10 & 120 & 53 & 50 & 6.361 & 48.9 & 0.447 & $0.1622 n$ \\
\hline Clay $\left(\mathrm{g} \mathrm{kg}^{-1}\right)$ & 10 & 190 & 64 & 50 & 19.55 & 66.3 & 1.248 & $0.1772 \ln$ \\
\hline \multicolumn{9}{|c|}{ Soil depth $0.2-0.3 \mathrm{~m}$} \\
\hline Carbon $\left(\mathrm{g} \mathrm{kg}^{-1}\right)$ & 1.5 & 23.0 & 6.1 & 4.4 & 22.03 & 77.5 & 1.794 & $0.0940 \mathrm{ln}$ \\
\hline $10 \mathrm{kPa}\left(\mathrm{cm}^{3} \mathrm{~cm}^{-3}\right)$ & 3.2 & 17.6 & 7.3 & 6.7 & 9.148 & 41.5 & 1.114 & $0.1193 \ln$ \\
\hline $80 \mathrm{kPa}\left(\mathrm{cm}^{3} \mathrm{~cm}^{-3}\right)$ & 1.4 & 15.2 & 4.5 & 3.7 & 8.374 & 63.8 & 1.622 & $0.1554 \ln$ \\
\hline $1500 \mathrm{kPa}\left(\mathrm{cm}^{3} \mathrm{~cm}^{-3}\right)$ & 1.1 & 12.6 & 3.3 & 2.7 & 4.978 & 68.1 & 1.825 & $0.1774 \ln$ \\
\hline EAWC $\left(\mathrm{cm}^{3} \mathrm{~cm}^{-3}\right)$ & 0.7 & 8.2 & 2.8 & 2.5 & 1.537 & 45.0 & 1.713 & $0.1540 \ln$ \\
\hline AWC $\left(\mathrm{cm}^{3} \mathrm{~cm}^{-3}\right)$ & 2.1 & 8.4 & 4.0 & 3.9 & 1.506 & 30.6 & 1.036 & $0.1263 \ln$ \\
\hline$\rho_{\mathrm{b}}\left(\mathrm{kg} \mathrm{dm}^{-3}\right)$ & 1.48 & 1.83 & 1.66 & 1.67 & $5.08 \mathrm{E}-03$ & 4.3 & -0.1555 & $0.0846 \mathrm{n}$ \\
\hline$\rho_{\mathrm{s}}\left(\mathrm{kg} \mathrm{dm}^{-3}\right)$ & 2.16 & 2.94 & 2.57 & 2.56 & $2.22 \mathrm{E}-02$ & 5.8 & $-9.70 \mathrm{E}-02$ & $0.1213 \mathrm{n}$ \\
\hline Sand $\left(\mathrm{g} \mathrm{kg}^{-1}\right)$ & 540 & 960 & 881 & 910 & 52.24 & 8.2 & -2.187 & $0.2182 \ln$ \\
\hline Silt $\left(\mathrm{g} \mathrm{kg}^{-1}\right)$ & 10 & 160 & 53 & 50 & 8.632 & 58.0 & 0.9003 & $0.1178 \ln$ \\
\hline Clay $\left(\mathrm{g} \mathrm{kg}^{-1}\right)$ & 10 & 300 & 66 & 50 & 25.8 & 76.9 & 2.079 & $0.2509 \ln$ \\
\hline
\end{tabular}

D - Maximum dispersion in relation to normal distribution; $\mathbf{n}-$ Normally distributed at a confidence interval $>0.95$; Ln - Log normally distributed at a confidence interval $>0.95$ (Kolmogorov-Smirnov statistic test).

to the upper depths. This may result from the fact that the $0.2-0.3 \mathrm{~m}$ layer is coincident to the upper boundary of a transitional zone to an argillic horizon (B) in the Ultisols. The small effect of this greater variance within the mean values of sand, silt and clay contents is explained by the small occurrence of sampling points with high clay contents.

The water retention capacity at 10,80 and $1,500 \mathrm{kPa}$, and the available water capacity (EAWC and AWC) decreased with increasing soil depth, which can be explained by the reduction of organic carbon content and a small increase in the clay content up to the $0.3 \mathrm{~m}$ depth, a common characteristic of the upper layers of the soils studied, especially the Paleudults (Planossolos, according to EMPRAPA, 2006), the most common soil class in the study site.

Analyzing the statistical parameters (Table 1) it is possible to evaluate the frequency distribution of 
the variables. Skewness values up to 0.5 suggest a specific attribute with normal distribution (Webster, 2001). Besides altimetry, the only attributes that showed both features, skewness smaller than 0.5 and normal distribution, at the three depths, were soil bulk density and particle density. Moreover, skewness values tended to increase with increasing soil depth, as well as the maximum errors of the frequency distribution tests (D values). This behavior can be evidenced by the attributes $10 \mathrm{kPa}, \mathrm{EAWC}$, and silt, for which the frequency distribution is normal at the upper depths and becomes lognormal as depth increases.

The smallest $\mathrm{CV}$ values $(>10 \%)$ were found for altitude, soil bulk density, particle density, and sand fraction content, at the three depths. The other attributes showed relatively high values $(>30 \%)$. The clay fraction had the highest $\mathrm{CV}$ values, and the $\mathrm{CV}$ for water retention increased proportionally to the water tension force. The high values of $\mathrm{CV}$ for clay content can be explained by the great amplitude of variation in the area (minimum e maximum values, Table 1), as well as, higher error associated to clay suction in the pipette method. In general, $\mathrm{CV}$ values increased with increasing soil depth, except for EAWC, AWC and soil bulk density. Variance and CV had a similar pattern for particle density, sand, silt, and clay fraction contents, and increased with depth. On the other hand, variance and $\mathrm{CV}$ for organic carbon content, water retention at field capacity, at $80 \mathrm{kPa}$, and at permanent wilting point decreased with increasing in depth.

Similar performance for water retention data was found by Mallants et al. (1996), observing the variance tendency to decrease with increasing depth, as the $\mathrm{CV}$ increases. Water release through more uniform pores may explain it, particularly for high water tension values. In this study, lower variance for high water tension values may be explained by water retention caused by adsorption rather than capillarity (as at 10 and $80 \mathrm{kPa}$ ), which is more erratic, since it is strongly controlled by porosity.

\section{Evaluation of semivariograms}

Experimental semivariograms, fitted models and respective parameters at each depth are presented in Table 2, and Figures 2, 3 and 4, respectively. Two types of semivariograms were observed, according to the variable and the soil depth. The first type, pure nugget effect, was observed for the silt fraction content (at the three depths) and particle density $(0.0-0.1 \mathrm{~m})$. The pure nugget effect indicates the absence of spatial correlation. This suggests that, for those variables at their respective depths, the mean, the median or the
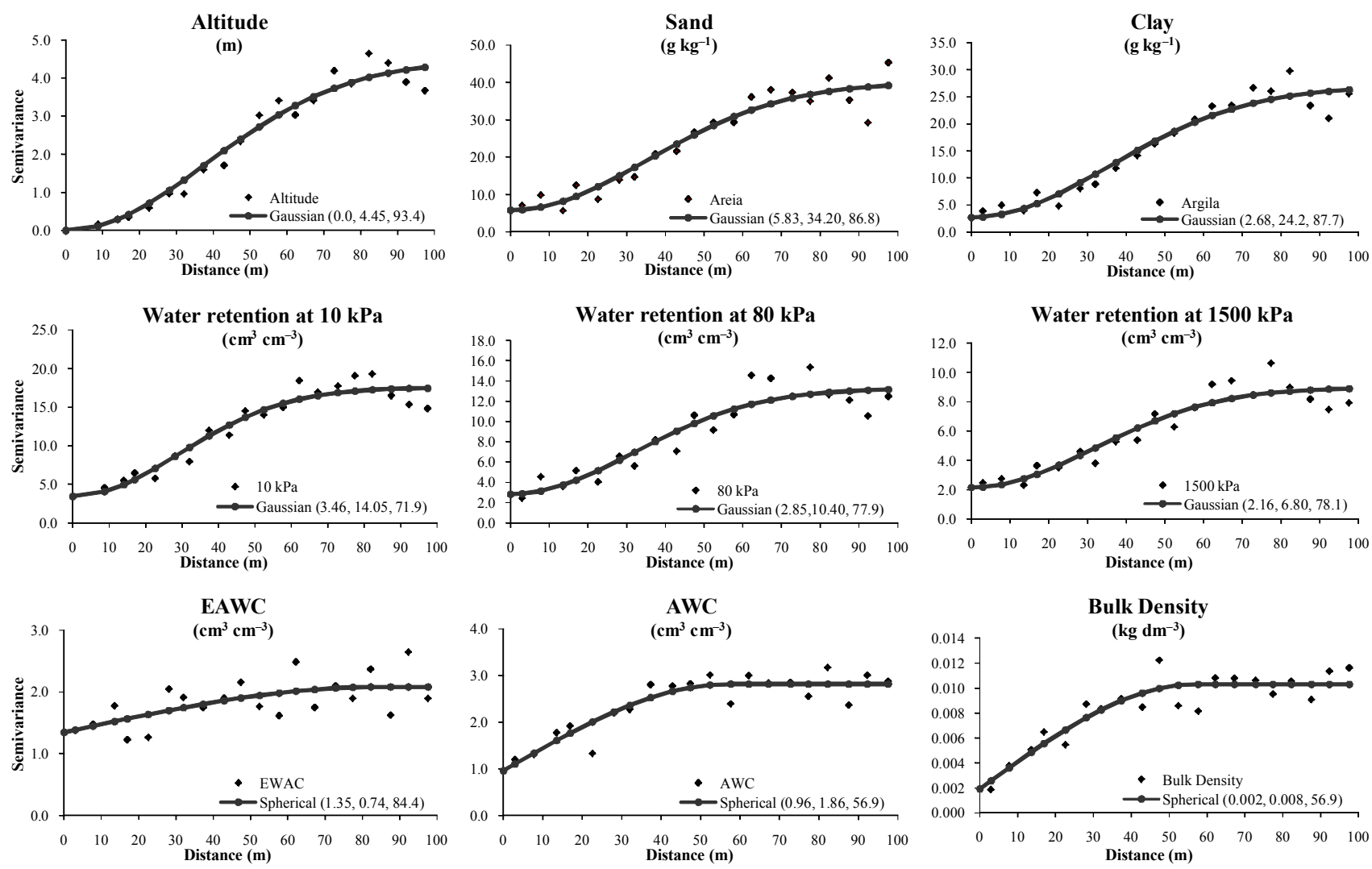

Figure 2 - Experimental and fitted theoretical semivariograms for altitude and the soil attributes at $0.0-0.1 \mathrm{~m}$ depth. 
Table 2 - Parameter values for the estimated theoretical semivariogram.

\begin{tabular}{|c|c|c|c|c|c|c|c|c|}
\hline Attributes & Model * & $\mathrm{C}_{\mathrm{o}}$ & $\mathrm{C}_{1}$ & $\mathrm{C} 0 /(\mathrm{Co}+\mathrm{C} 1) * 100$ & Range & $\mathrm{r}^{2}$ & $\begin{array}{l}\text { Variance of } \\
\text { reduced error }\end{array}$ & $\begin{array}{c}\text { Mean of } \\
\text { reduced error }\end{array}$ \\
\hline & & & & $\%$ & $\mathrm{~m}$ & & & \\
\hline \multicolumn{9}{|c|}{ Soil depth $0.0-0.1 \mathrm{~m}$} \\
\hline Altitude & Gaussian & & & & & & & \\
\hline $10 \mathrm{kPa}$. & Gaussian & & & & & & & 3.635 \\
\hline $80 \mathrm{kPa}$. & Gaussian & 2.85 & 10.40 & 21.5 & 77.9 & 0.87 & 1.057 & $-4.47 \mathrm{E}-03$ \\
\hline $1500 \mathrm{kPa}$. & Gaussian & 2.16 & 6.80 & & 78.1 & & & \\
\hline EAWC & Spherical & & & 64.6 & & & & 77E-02 \\
\hline AWC & Spherical & 0.96 & & 34.0 & & & & \\
\hline$\rho_{\mathrm{b}}$ & Spherical & & & 20.0 & 56.9 & & 1.388 & \\
\hline$\rho_{\mathrm{s}}$ & Pure nugget & - & - & - & - & - & - & - \\
\hline Sand & Gaussian & 5.83 & 34.20 & 14.6 & 86.8 & & 1.142 & \\
\hline Silt & Pure nugget & - & - & - & - & - & - & - \\
\hline Clay & Gaussian & & & & & & & \\
\hline \multicolumn{9}{|c|}{ Soil depth $0.1-0.2 \mathrm{~m}$} \\
\hline $10 \mathrm{kPa}$. & Spherical & 0.0 & 11.31 & 0.0 & 76.4 & & 1.910 & \\
\hline $80 \mathrm{kPa}$. & Spherical & & & & & & & \\
\hline $1500 \mathrm{kPa}$. & Spherical & & & & & & & $2.92 \mathrm{E}-02$ \\
\hline EAWC & Spherical & 1.25 & 0.72 & & & & & \\
\hline AWC & Spherical & 0.0 & 1.84 & & & & & \\
\hline$\rho_{\mathrm{b}}$ & Spherical & & & 71.0 & 41.5 & & & $-3.41 \mathrm{E}-02$ \\
\hline$\rho_{\mathrm{s}}$ & Spherical & & 0.27 & 0.0 & & & 0.203 & -0.01848 \\
\hline Sand & Gaussian & 6.97 & 36.01 & & & & & \\
\hline Silt & Pure nugget & - & - & - & - & - & - & - \\
\hline Clay & Gaussian & & & 16.6 & & & & \\
\hline \multicolumn{9}{|c|}{ Soil depth $0.2-0.3 \mathrm{~m}$} \\
\hline $10 \mathrm{kPa}$. & Gaussian & & & & & & & \\
\hline $80 \mathrm{kPa}$ & Gaussian & & & & & & & \\
\hline $1500 \mathrm{kPa}$. & Gaussian & & & & & & & \\
\hline EAWC & Spherical & & & & & & & \\
\hline AWC & Spherical & 0.0 & 1.74 & 0.0 & & & & -0.1994 \\
\hline$\rho_{\mathrm{b}}$ & Spherical & & & & & & & \\
\hline$\rho_{\mathrm{s}}$ & Spherical & & & & 40.0 & & & \\
\hline Sand & Gaussian & 8.03 & 60.0 & & & & & \\
\hline Silt** & Pure nugget & - & - & - & - & - & - & - \\
\hline Clay & Gaussian & & & & & & & \\
\hline
\end{tabular}

*Models fitted according to Jack-nife procedure. **After removal of the linear trend.

mode may be the best estimator in any point of the studied area, if distribution is normal (Journel \& Huijbregts, 1978).

In the second type, increasing distance (h) resulted in an increased $\gamma(\mathrm{h})$, up to a maximum stable value. The distance at which $\gamma(\mathrm{h})$ reaches stability is called range (a), and it is defined as the limit distance of spatial dependence (Vieira, 2000). Altitude, sand and clay fractions, water retention at 10,80 and $1,500 \mathrm{kPa}$, EAWC, AWC, soil bulk density and particle density (at the depth $0.2-0.3 \mathrm{~m}$ ), presented this type of semivariogram. This in agreement to the intrinsic hypothesis, and may be considered that the stationary of order 2.

Altitude, sand and clay contents (at the three depths) fitted a Gaussian model, but soil bulk density, particle density (except at $0-0.10 \mathrm{~m}$ depth), EAWC and AWC showed a pattern of spherical model at the three depths. Some attributes showed patterns matching different models with soil depth, as water retention capacity at 10,80 and $1500 \mathrm{kPa}$. In this case, the Gaussian model fitted at depths $0.0-0.10 \mathrm{~m}$ and 0.20 

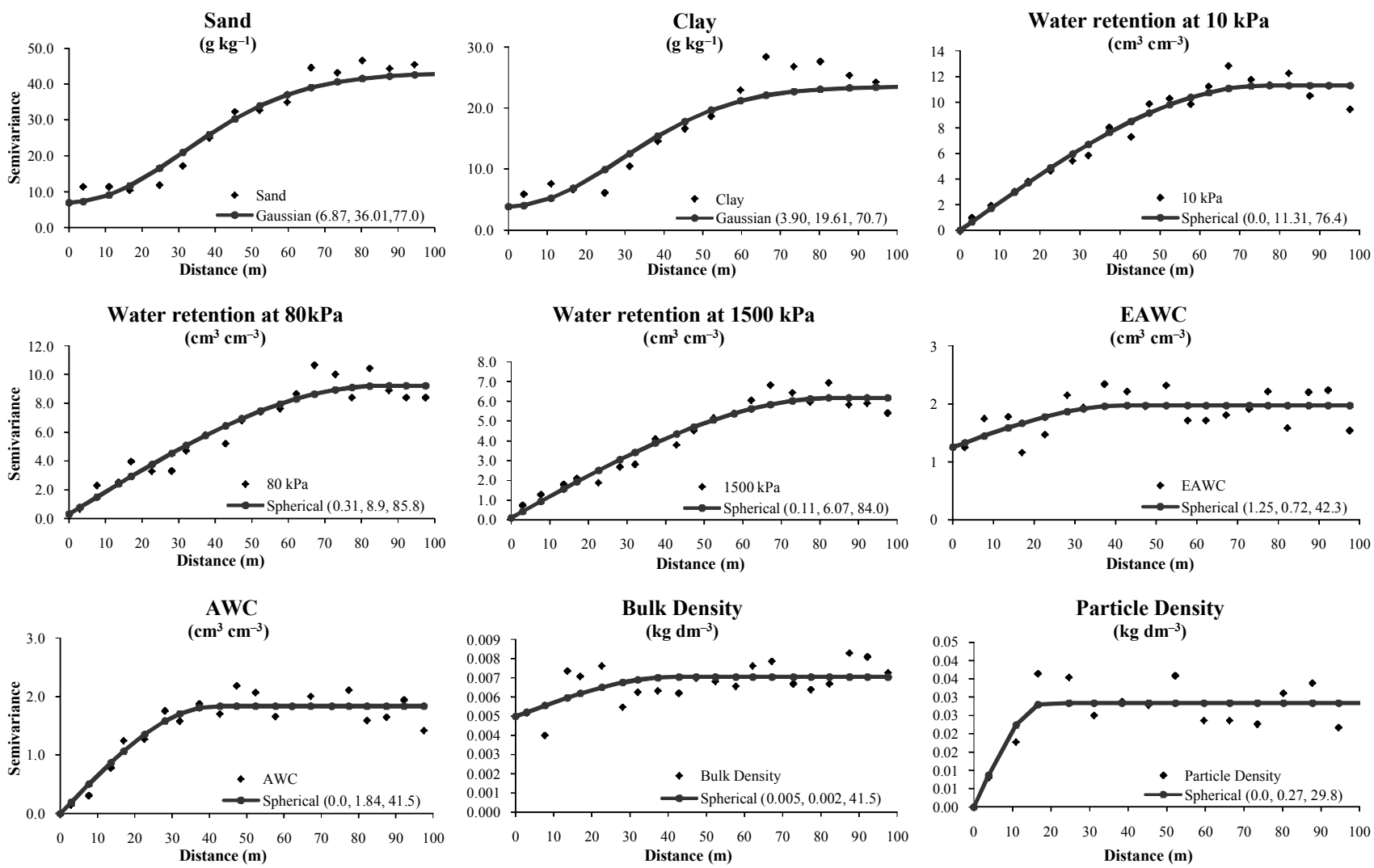

Figure 3 - Experimental and fitted theoretical semivariograms for the soil attributes at $0.1-0.2 \mathrm{~m}$ depth.
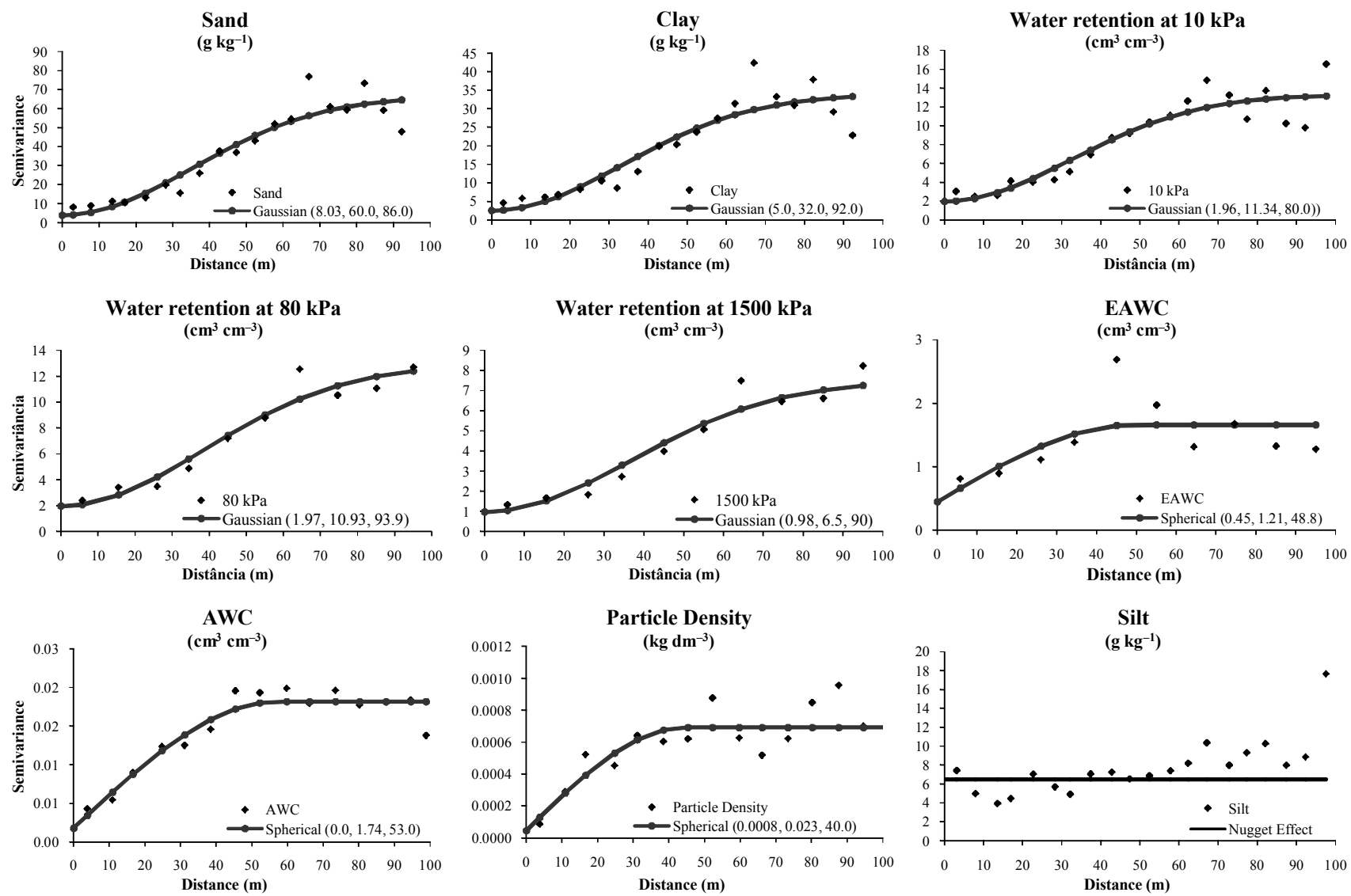

Figure 4 - Experimental and fitted theoretical semivariograms for the soil attributes at $0.2-0.3 \mathrm{~m}$ depth. 
$0.30 \mathrm{~m}$, and the spherical model at the $0.10-0.20 \mathrm{~m}$ depth. The type of the model matching the data distribution suggests the spatial continuity of the phenomenon investigated (Isaaks \& Srivastava, 1989). The Gaussian model describes a more continuous random function, and the spherical model a relatively more erratic random function. The major occurrence of spherical models at the depth of $0.10-0.20 \mathrm{~m}$ suggests a rather erratic pattern, as it is observed for sand and
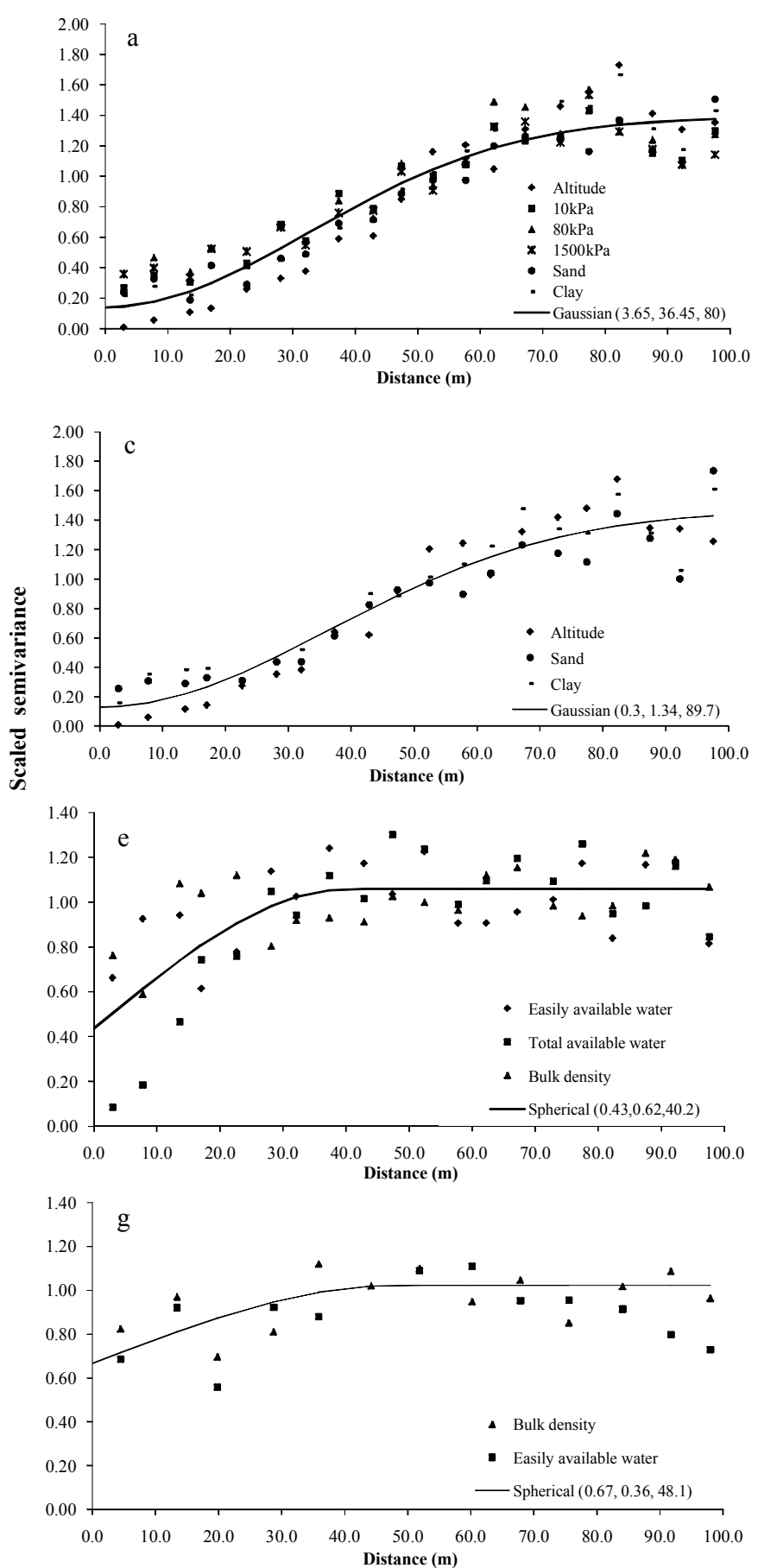

Figure 5 - Experimental and fitted theoretical scaled semivariograms for altitude and the soil attributes at $0.0-0.1$ (5a and $5 \mathrm{~b}), 0.1-0.2$ (5c, 5d and 5e), and $0.2-0.3 \mathrm{~m}$ (5f and $5 \mathrm{~g}$ ) depth. clay fractions that, despite showing the Gaussian model, showed a relative increase of the nugget effect and a decrease in the range values.

When the range is evaluated, EAWC (except for the depth of $0-0.10 \mathrm{~m})$, AWC, soil bulk density and particle density showed a smaller spatial dependence to the other attributes. There are differences in how the nugget effect affects total data variance in those attributes, indicating that the spatial dependence
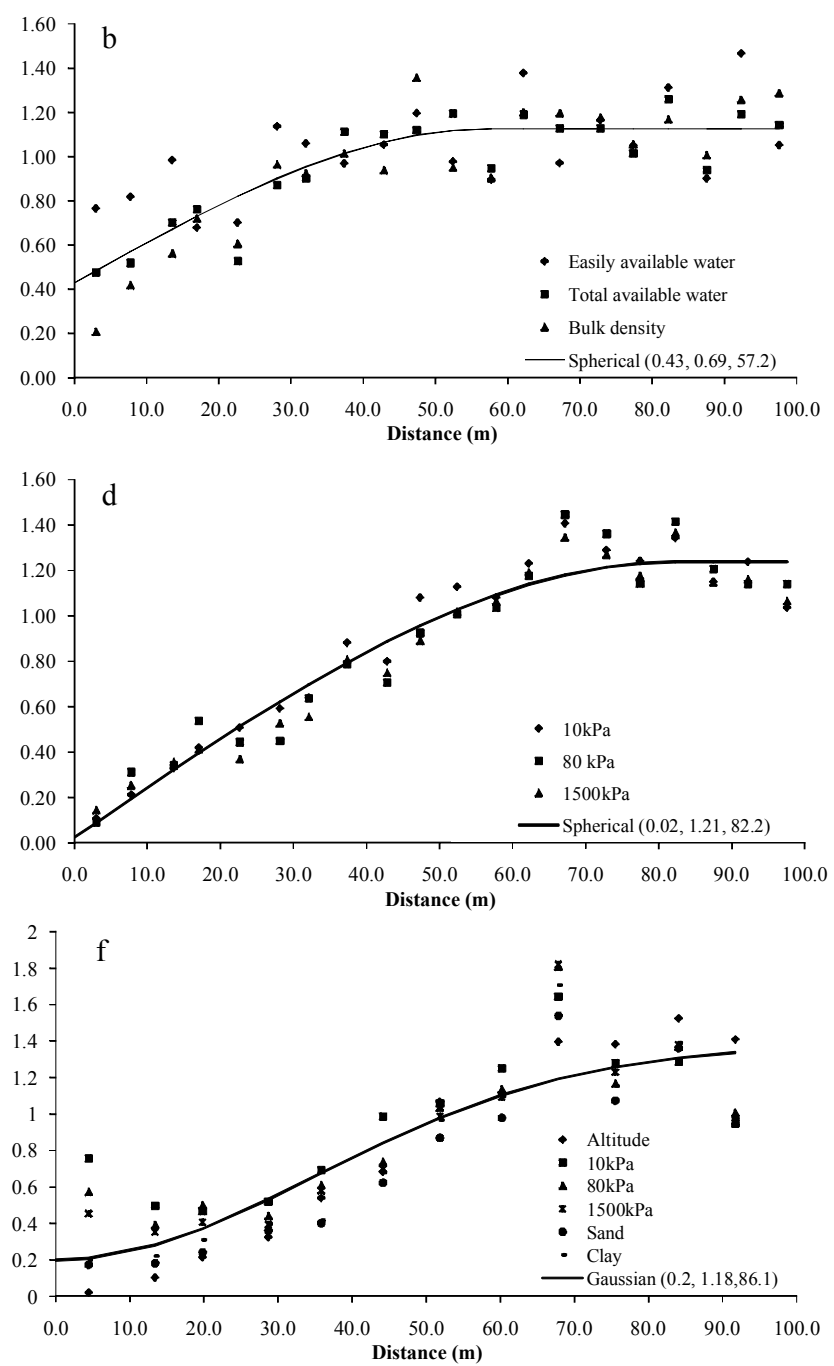
index (SDI), proposed by Cambardella et al. (1994) is sometimes inadequate to evaluate spatial dependence. This difference is clearly evidenced in EAWC values for the depths $0-0.1 \mathrm{~m}$ and $0.2-0.3 \mathrm{~m}$, when the ranges with the semivariograms SDI are compared. According to the range analysis, there is a decrease in spatial dependence.

The range analysis indicates that there is a decrease in spatial dependence for EAWC as depth increases, since SDI values increase with depth. SDI low values do not necessarily mean low spatial dependence. Otherwise, the experimental procedure (either because of the sampling grid adopted or by non-controlled errors during the attribute determination) may have not allowed an adequate characterization of spatial dependence.

\section{Scaled semivariograms}

At each depth, semivariograms were scaled for attributes that fitted to the same model (Vieira et al.,

Table 3 - Correlation matrix of soil attributes, lower triangles.

\begin{tabular}{|c|c|c|c|c|c|c|c|c|c|c|c|}
\hline & Altitude & $10 \mathrm{kPa}$ & $80 \mathrm{kPa}$ & $1500 \mathrm{kPa}$ & EAWC & $\mathrm{AWC}$ & $\rho_{\mathrm{b}}$ & $\rho_{\mathrm{s}}$ & Sand & Silt & Clay \\
\hline \multicolumn{12}{|c|}{ Soil depth $0.0-0.10 \mathrm{~m}$} \\
\hline Altitude & 1 & & & & & & & & & & \\
\hline $10 \mathrm{kPa}$ & 0.487 & 1 & & & & & & & & & \\
\hline $80 \mathrm{kPa}$ & 0.533 & 0.928 & 1 & & & & & & & & \\
\hline $1500 \mathrm{kPa}$ & 0.541 & 0.911 & 0.954 & 1 & & & & & & & \\
\hline EAWC & 0.053 & 0.491 & 0.130 & 0.192 & 1 & & & & & & \\
\hline AWC & 0.202 & 0.732 & 0.499 & 0.387 & 0.781 & 1 & & & & & \\
\hline$\rho_{\mathrm{b}}$ & 0.077 & -0.301 & -0.240 & -0.240 & -0.238 & -0.278 & 1 & & & & \\
\hline$\rho_{\mathrm{s}}$ & -0.003 & -0.114 & -0.068 & -0.038 & -0.144 & -0.194 & 0.249 & 1 & & & \\
\hline Sand & -0.514 & -0.845 & -0.863 & -0.827 & -0.231 & -0.525 & 0.098 & 0.041 & 1 & & \\
\hline Silt & 0.004 & 0.504 & 0.451 & 0.444 & 0.286 & 0.397 & -0.231 & -0.026 & -0.661 & 1 & \\
\hline Clay & 0.669 & 0.795 & $\mathbf{0 . 8 4 7}$ & $\mathbf{0 . 8 0 7}$ & 0.136 & 0.447 & -0.002 & -0.062 & -0.888 & 0.257 & 1 \\
\hline \multicolumn{12}{|c|}{ Soil depth $0.10-0.20 \mathrm{~m}$} \\
\hline Altitude & 1 & & & & & & & & & & \\
\hline $10 \mathrm{kPa}$ & 0.501 & 1 & & & & & & & & & \\
\hline $80 \mathrm{kPa}$ & 0.503 & 0.891 & 1 & & & & & & & & \\
\hline $1500 \mathrm{kPa}$ & 0.499 & 0.920 & 0.937 & 1 & & & & & & & \\
\hline EAWC & 0.104 & 0.437 & -0.019 & 0.169 & 1 & & & & & & \\
\hline AWC & 0.300 & 0.732 & 0.448 & 0.407 & 0.726 & 1 & & & & & \\
\hline$\rho_{\mathrm{b}}$ & 0.103 & -0.234 & -0.121 & -0.149 & -0.277 & -0.286 & 1 & & & & \\
\hline$\rho_{\mathrm{s}}$ & 0.244 & -0.023 & 0.033 & 0.046 & -0.116 & -0.134 & 0.207 & 1 & & & \\
\hline Sand & -0.502 & -0.802 & -0.866 & -0.855 & -0.050 & -0.384 & 0.048 & -0.043 & 1 & & \\
\hline Silt & 0.155 & 0.336 & 0.355 & 0.358 & 0.036 & 0.162 & 0.081 & -0.122 & -0.550 & 1 & \\
\hline Clay & 0.530 & 0.655 & 0.792 & 0.726 & -0.126 & 0.266 & -0.019 & 0.124 & -0.779 & 0.438 & 1 \\
\hline \multicolumn{12}{|c|}{ Soil depth $0.20-0.30 \mathrm{~m}$} \\
\hline Altitude & 1 & & & & & & & & & & \\
\hline $10 \mathrm{kPa}$ & 0.469 & 1 & & & & & & & & & \\
\hline $80 \mathrm{kPa}$ & 0.482 & 0.914 & 1 & & & & & & & & \\
\hline $1500 \mathrm{kPa}$ & 0.488 & 0.935 & 0.971 & 1 & & & & & & & \\
\hline EAWC & 0.042 & 0.373 & -0.034 & 0.083 & 1 & & & & & & \\
\hline AWC & 0.273 & 0.787 & 0.519 & 0.519 & 0.759 & 1 & & & & & \\
\hline$\rho_{\mathrm{b}}$ & 0.050 & -0.122 & -0.018 & -0.019 & -0.256 & -0.255 & 1 & & & & \\
\hline$\rho_{\mathrm{s}}$ & 0.172 & 0.060 & 0.033 & 0.019 & 0.071 & 0.107 & -0.030 & 1 & & & \\
\hline Sand & -0.521 & -0.810 & -0.878 & -0.908 & 0.026 & -0.367 & -0.099 & -0.086 & 1 & & \\
\hline Silt & 0.246 & 0.550 & 0.553 & 0.609 & 0.075 & 0.259 & 0.191 & 0.117 & -0.792 & 1 & \\
\hline Clay & 0.570 & 0.821 & 0.907 & 0.918 & -0.061 & 0.378 & 0.042 & 0.053 & -0.937 & 0.536 & 1 \\
\hline
\end{tabular}

Values of Pearson correlation in blank are significant for $p<0.05$ 
1997). Figure 5 shows the scaled semivariograms for these variables, at depths $0.0-0.1$ ( $5 \mathrm{a}$ and $5 \mathrm{~b}$ ), $0.1-$ 0.2 (5c, 5d and 5e), and $0.2-0.3 \mathrm{~m}(5 \mathrm{f}$ and $5 \mathrm{~g}$ ), respectively. At the depth of $0.0-0.1 \mathrm{~m}$ (Figure 5a), clay and sand fraction contents, water retention at 10, 80 and $1,500 \mathrm{kPa}$, and altitude were clustered into the same graph, since they fitted to the Gaussian model. Semivariograms similarity showed that those variables had similar patterns for spatial variability, reaching the range of $80 \mathrm{~m}$. The greatest difference could be observed in the parabolic portion close to the origin (20 meters), as a consequence of the major nugget effect of the soil physical attributes. At the depth of $0.2-0.3$ $\mathrm{m}$ (Figure 5f), the same attributes were grouped in a similar way, but both the nugget effect and the range of the fitted model were greater than values observed for the $0.0-0.1 \mathrm{~m}$. It is suggested that, despite spatial dependence increases at depth of 0.2-0.3 $\mathrm{m}$ (range of 86,1 meters), there was an increase in the erratic component of the semivariance, especially for water retention at 10,80 and $1,500 \mathrm{kPa}$, which showed greater

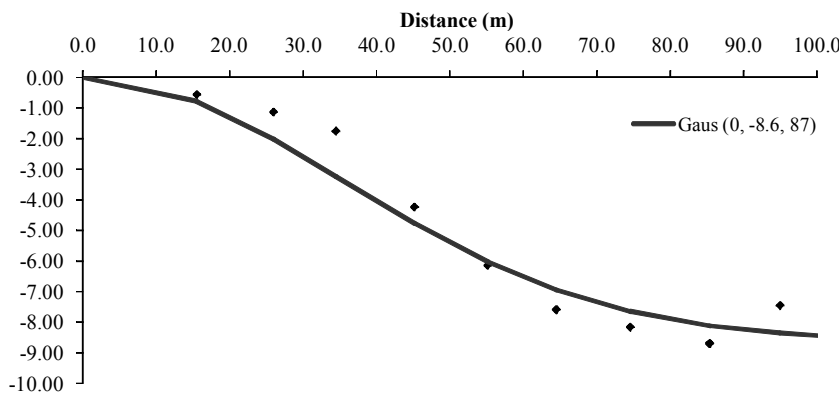

Sand x Altitude
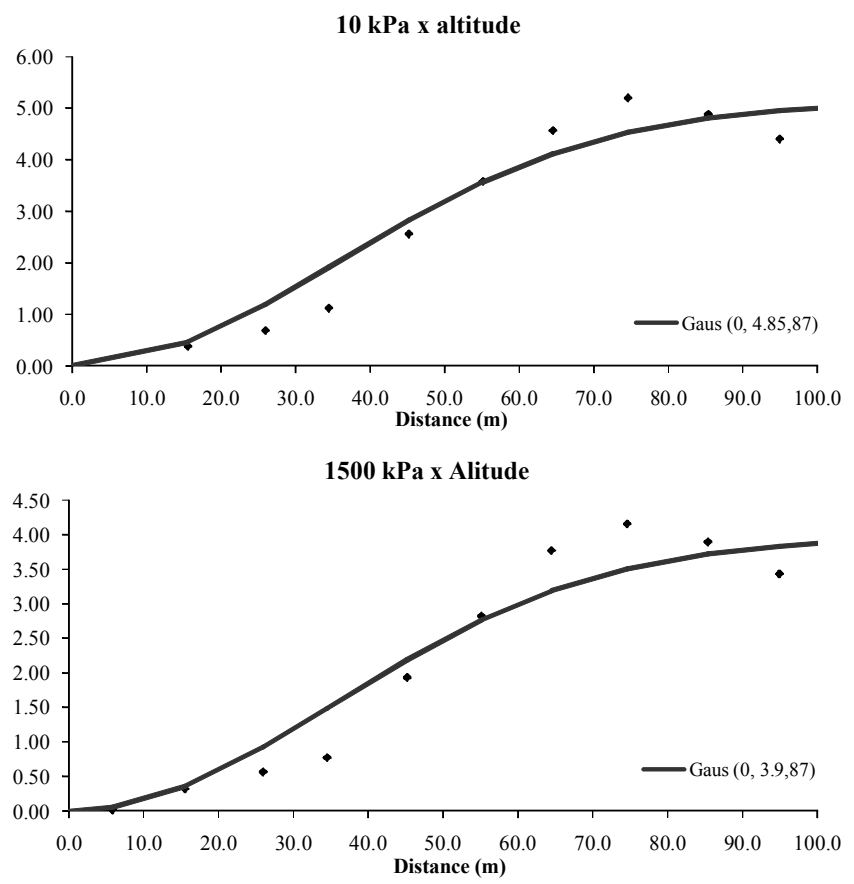

source of errors due to the use of undisturbed soil samples for the laboratorial procedure on water extraction with Richards membrane.

Figures $5 \mathrm{~b}, 5 \mathrm{e}$ and $5 \mathrm{~g}$ show results for EAWC, AWC and soil bulk density, at depths $0.0-0.1$, $0.1-0.2$ and $0.2-0.3 \mathrm{~m}$, respectively. Differently of former variables with Gaussian model, there is not a clear similarity in the variability pattern of those attributes. At the three depths the spherical model was fitted, with a range between 40 and $60 \mathrm{~m}$. Spatial dependence was found to be smaller at depths $0.1-0.2$ and $0.2-0.3 \mathrm{~m}$. There was a smaller grouping of attributes with semi variance data for the fitted models, especially for the nugget effect of soil bulk density at depth $0.0-0.1 \mathrm{~m}$ (Figure 5b), and EAW at depth $0.1-0.2 \mathrm{~m}$ (Figure 5e).

Altitude, sand and clay fractions semivariograms at $0.1-0.2 \mathrm{~m}$ the depth were grouped into the same graph (Figure 5c). Similarly to $0.0-0.1$ $\mathrm{m}$ the depth, those attributes fitted the Gaussian model, with a range of approximately $90 \mathrm{~m}$, and greater er-
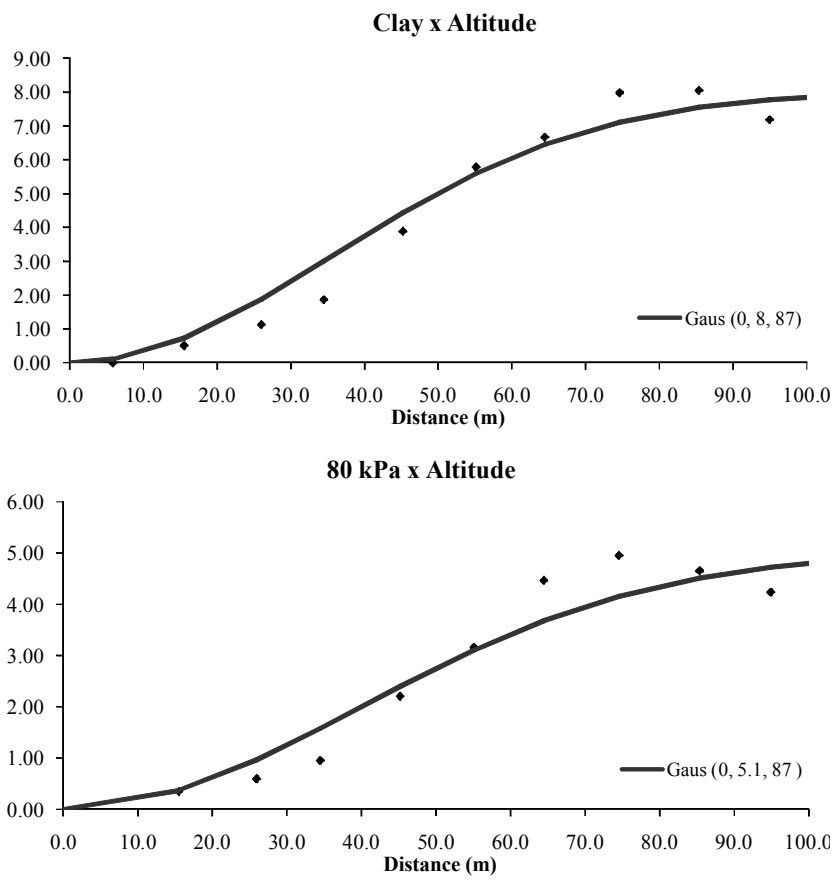

Figure 6 - Experimental and fitted theoretical cross-semivariograms for altitude and soil physics attributes at $0.0-0.1 \mathrm{~m}$ depth. 
rors of the semi variances in relation to the model fitted in the parabolic portion (upper $20 \mathrm{~m}$ ), as a consequence of the major nugget effect found for the sand and clay. Water retention at field capacity, $80 \mathrm{kPa}$ and PWP (Figure 5d), differently of observed at depths 0.0 $0.1 \mathrm{~m}$ and $0.2-0.3 \mathrm{~m}$, were grouped in to one graph with a spherical model. The similarity in how those attributes vary must be emphasized. It is evidenced by the greater grouping of semi variance data according to the fitted model, and by small differences in nugget effect and range.

\section{Correlation between soil attributes and cross- semivariograms}

Table 3 shows Pearson correlation coefficients between all the variables. Correlation between altitude and sand and clay fraction contents was found to be significant, as well as, between altitude and water retention at 10,80 and $1,500 \mathrm{kPa}$. Coefficients showed a tendency to decrease as depth increased, suggesting that effects of height on soil physical attributes may decrease as soil depth increases. The results agree with the pattern observed in scaled semivariograms, i.e., altitude and some physical-hydric attributes show a similar variability pattern, presenting a trend for a decrease as soil depth increases.

In the coastal low hills of Rio de Janeiro State, soils are predominantly formed by material originated of in situ weathering of Precambrian rocks (leuco and mesocratic gneisses), and of their derived colluvial and alluvial sediments (Silva et al., 2001). On the top and the upper third of the slopes the materials are usually loamy or clayey textured; on the lower section of the slope, and some of the lowlands, sandy colluvial sediments are dominant on the surface, and stratified sediments are a characteristic of the alluvial sites. The sediments with high sand contents in the lowlands may explain the negative correlation between altitude and sand fraction content, as well as the negative correlation of sand content with water retention at 10,80 and $1,500 \mathrm{kPa}$, and with water availability.
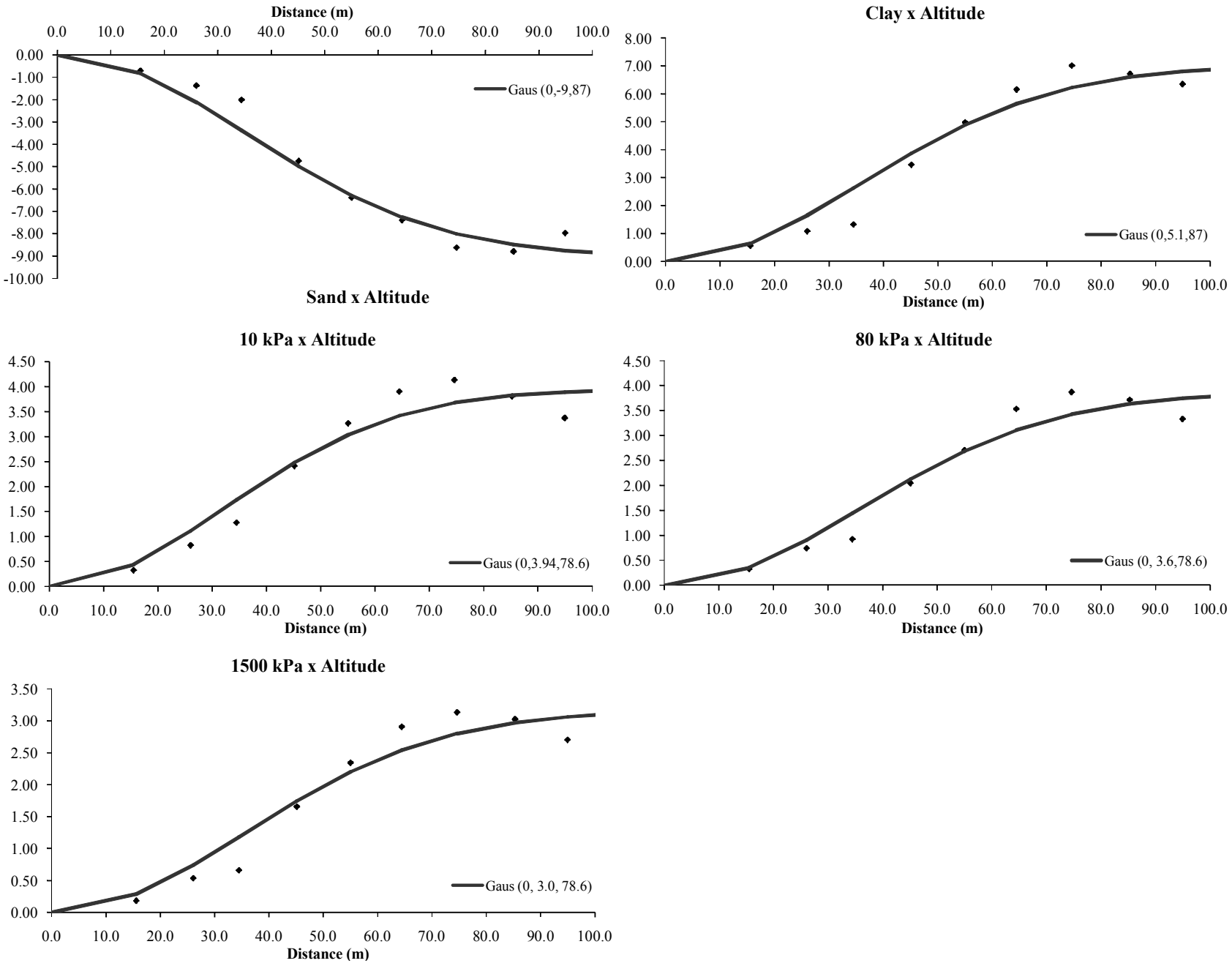

Figure 7 - Experimental and fitted theoretical cross-semivariograms for altitude and soil physical attributes at $0.1-0.2 \mathrm{~m}$ depth. 


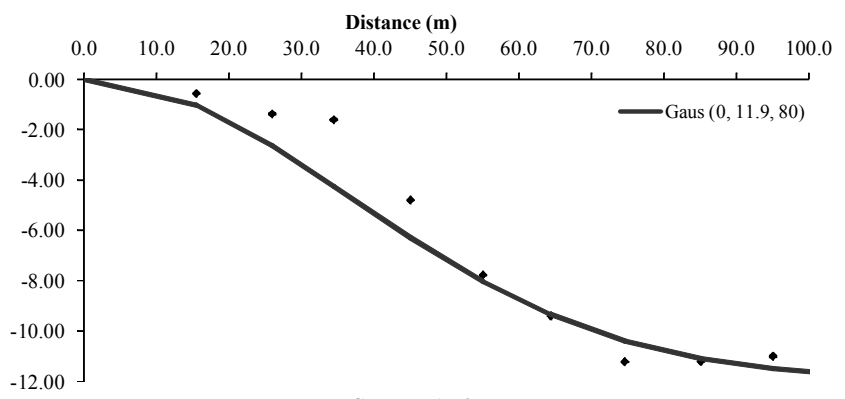

Sand $x$ Altitude
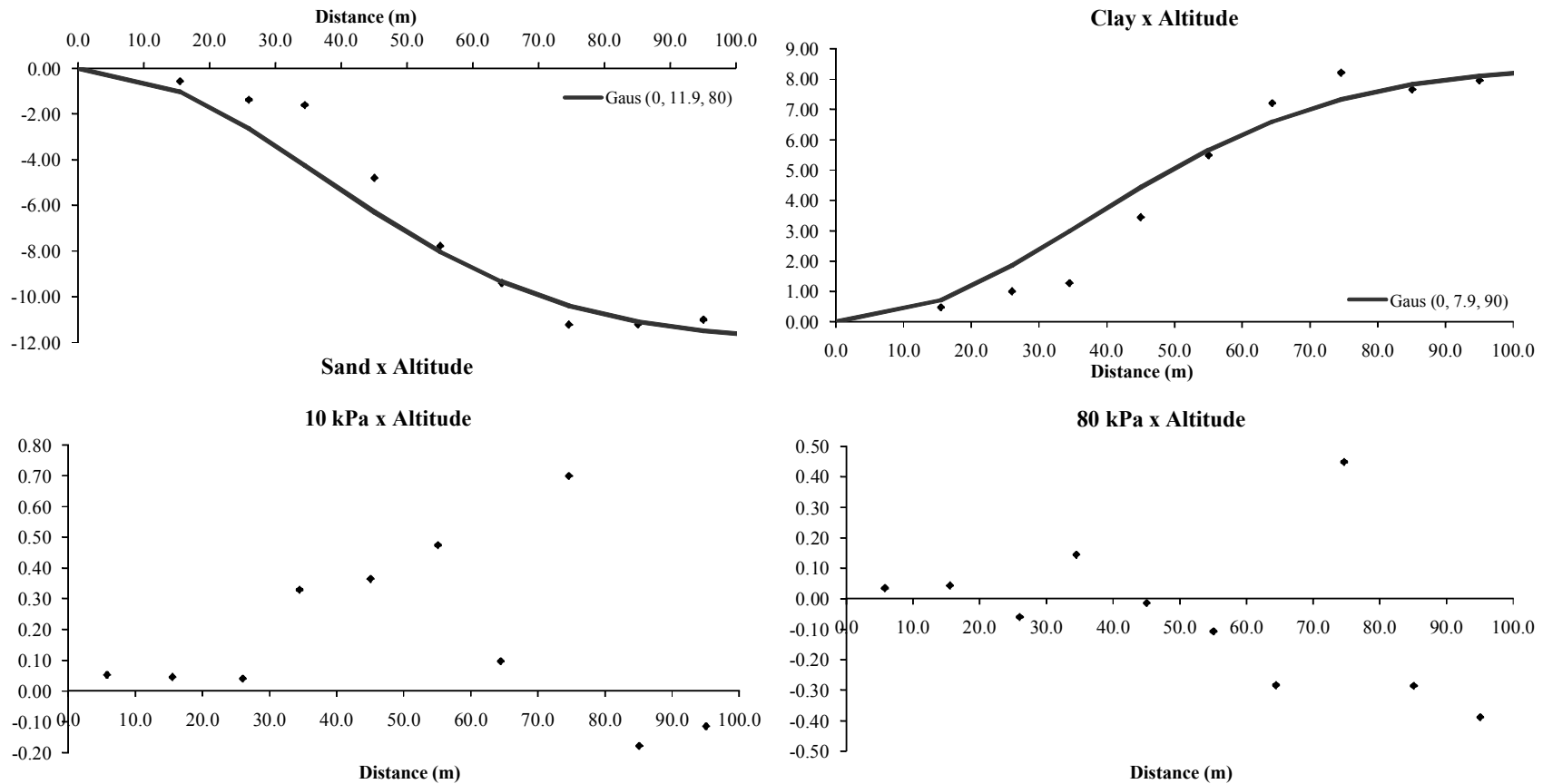

Distance (m)

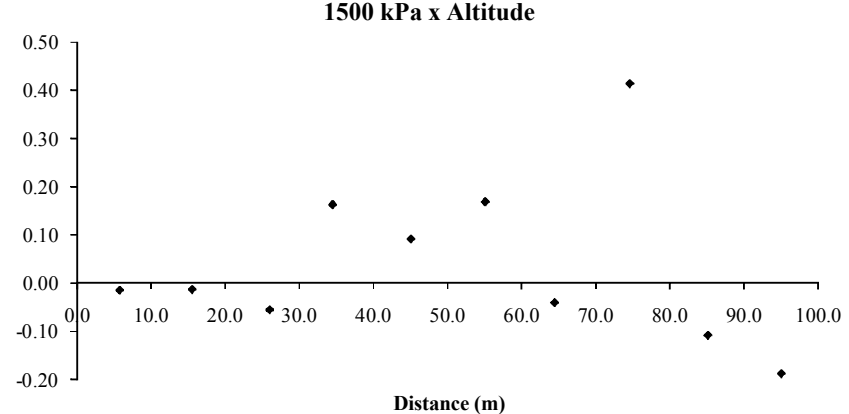

Figure 8 - Experimental and fitted theoretical cross-semivariograms for altitude and soil physical attributes at $0.2-0.3 \mathrm{~m}$ depth.

Coefficients of correlation were found to be greatest between water retention at 10,80 and 1,500 $\mathrm{kPa}$, which were also found to be strongly correlated with sand and clay fraction contents. At depths $0-0.1$ $\mathrm{m}$ and $0.1-0.2 \mathrm{~m}$, the water content at field capacity $(80 \mathrm{kPa})$ and permanent wilting point were more strongly correlated with sand content. As for the depth $0.2-0.3 \mathrm{~m}$, there was a greater correlation with the clay content. This pattern may result from the fact that clay content in the soil increases with depth. Despite this increase being considered small, it was responsible for the greatest errors (minimum and maximum values Table 1).

In addition of being the most used statistical tool to evaluate the relationship between two variables, the coefficient of correlation is also used in geostatistic to improve data interpolation. Because of the highly significant coefficients of correlation, cross semivariograms were performed to compare the most interesting and harder to determine (principal variables) physical-hydric attributes with altitude (auxil- iary variable). Cross-semivariograms are applied to analyze data because auxiliary variables, especially those correlated with a principal variable, may improve their estimation (Isaaks \& Srivastava, 1989). Figures 6,7 and 8 present cross-semivariograms between altitude and sand and clay fraction contents, and between altitude and water retention at 10,80 and 1,500 $\mathrm{kPa}$, at depths $0.0-0.1,0.1-0.2$ and $0.2-0.3 \mathrm{~m}$, respectively. At depths $0.0-0.1$ and $0.1-0.2 \mathrm{~m}$ (Figures 6 and 7) altitude may be used as a secondary variable, both for sand and clay, and also for water retention at 10,80 and $1,500 \mathrm{kPa}$. At depth $0.2-0.3 \mathrm{~m}$, this tool was found to be viable only for sand and clay contents (Figure 8). All the cross-semivariograms fitted to both Gaussian model and pure nugget effect. The smaller nugget effect, when compared to individual semivariograms of physical-hydric attributes, showed a greater spatial continuity in short distances, which is expected for variables with strong linear correlation (Paz-González et al., 2000). At the depth of $0.0-0.1 \mathrm{~m}$, all the cross-semivariograms showed the 

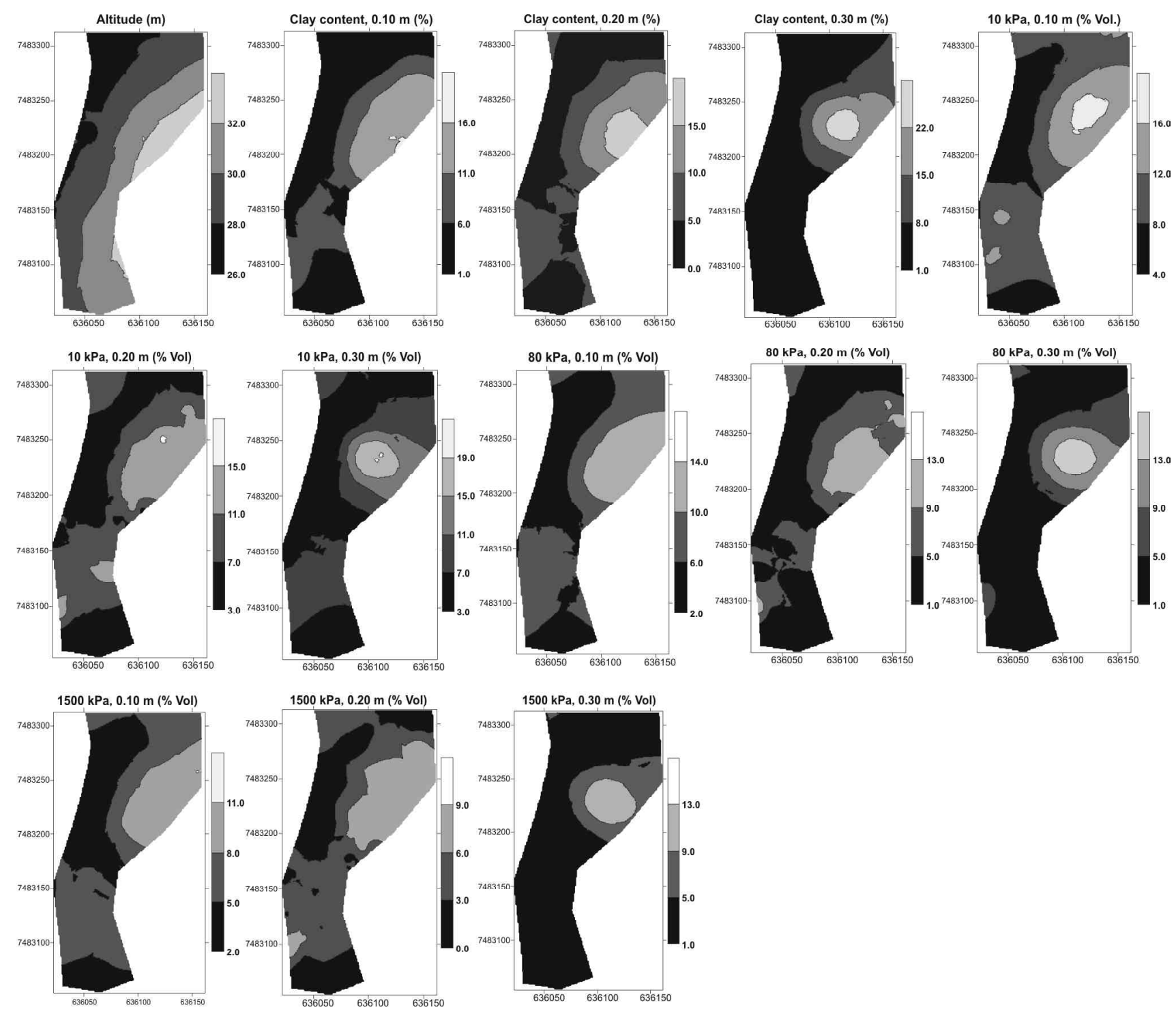

Figura 9 - Spatial variability maps of altitude, clay content and water retention at 10, 80 and $1500 \mathrm{kPa}$.

same range $(87 \mathrm{~m})$, as it was observed for sand and clay fraction contents at the depth of $0.1-0.2 \mathrm{~m}$. Water retention at 10,80 and $1,500 \mathrm{kPa}$, at the depth of 0.1-0.2 $\mathrm{m}$, had a lower spatial dependence (range of $78.6 \mathrm{~m}$ ). The lack of a cross-semivariogram between altitude and water retention at 10,80 and $1,500 \mathrm{kPa}$, at depth $0.2-0.3 \mathrm{~m}$, and the decrease of range with depth increasing, both results agree with the respective coefficients of correlation with soil depth, as well as with the characteristics of scaled semivariograms.

The kriged maps of all the variables, at all soil depth, are presented at figures 9 (altitude, clay content and water retention at 10,80 and $1,500 \mathrm{kPa}$ ) and figure 10 (EAWC, AWC Bulk and Particle Density). In figure 9 it is possible to visualize the similarity between spatial variability pattern of altitude and the soil physics attributes. The higher the elevation, higher the clay content as well as water retention at 10,80 and $1,500 \mathrm{kPa}$. Besides, as soil depth increased, higher the similarity between spatial variability patterns of clay content and water retention at 10,80 and $1,500 \mathrm{kPa}$, showing the high influence of texture over water retention. The pattern of similarity between spatial variability observed in figure 9 is not the same in figure 10. Bulk density and particle density do not follow the similar pattern of elevation and clay content, as well as, EAWC and AWC, especially at $0.0-0.1 \mathrm{~m}$ depth. These results are in accordance with the analysis of scaled and cross semivariograms.

\section{CONCLUSIONS}

Areas with higher elevation presented higher values of clay content, as well as, soil water retention at 10,80 and $1,500 \mathrm{kPa}$. The correlation between altitude and soil physical attributes decreased as soil depth 

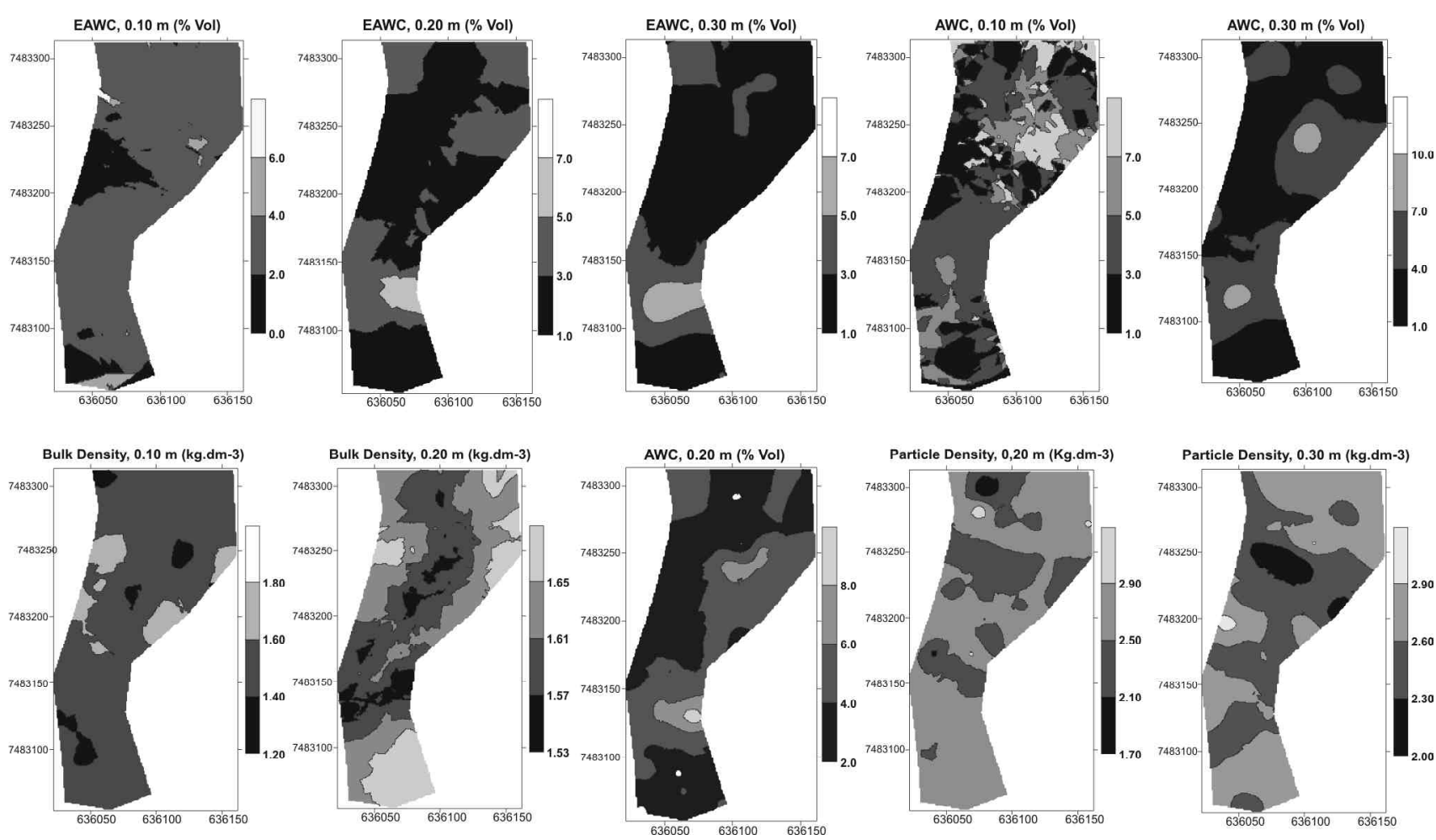

Figure 10 - Spatial variability maps of EAWC, AWC, bulk density and particle density.

increased. The cross semivariograms demonstrated the viability in using altitude as an auxiliary variable to improve the interpolation of sand and clay contents to estimate data at the depth of $0.0-0.3 \mathrm{~m}$, and of water retention at 10,80 and $1,500 \mathrm{kPa}$ at the depth of 0.0 $0.2 \mathrm{~m}$

\section{REFERENCES}

ADDINSOFT. XLSTAT-PLS 1.8: statistical software to MS Excel. New York: Addinsoft, 2004.

AYRES, M.; AYRES JÚNIOR, M.; AYRES, D.L.; SANTOS, A.S. BioEstat 2.0: aplicações estatísticas nas áreas das ciências biológicas e médicas. Belém: Sociedade Civil Mamiraua/CNPq, 2003.

CAMBARDELLA, C.A.; MOORMAN, T.B.; NOVAK, J.M.; PARKIN, T.B.; KARLEN, D.L.; TURCO, R.F.; KONOPKA, A.E. Field-scale variability of soil properties in central Iowa soils. Soil Science Society of America Journal, v.58, p.1501-1511, 1994.

EMBRAPA. Centro Nacional de Pesquisas de Solos. Sistema brasileiro de classificação de solos. 2 ed. Rio de Janeiro: Embrapa Solos, 2006 605p.

EMPRESA BRASILEIRA DE PESQUISA AGROPECUÁRIA EMBRAPA. Manual de métodos de análise de solo. Rio de Janeiro: Embrapa, 1997. 247p.

EMPRESA BRASILEIRA DE PESQUISA AGROPECUÁRIA EMBRAPA. Levantamento semidetalhado dos solos da área do Sistema Integrado de Produção Agroecológica (SIPA) - km 47 - Seropédica, RJ. Rio de Janeiro: Embrapa Solos, 1999. 93p. (Boletim de Pesquisa, 5).

GOOVAERTS, P. Geoestatistics in soil science: state-of-the-art and perspectives. Geoderma, v.89, p.1-46, 1997.

JOURNEL, A.G. ; HUIJBREGTS, C.H.J. Mining geoestatistics. London: Academic Press, 1978. 600p.
ISAAKS, E.H.; SRIVASTAVA, R.M. Applied geoestatistics. Oxford: Oxford University Press, 1989. 560p.

KREZNOR, W.R.; OLSON, K.R.; BANWART, W.L.; JOHNSON, D.L. Soil, lanbulk densitycape, and erosion relationships in a northwest Illinois watershed. Soil Science Society of America Journal, v.53, p.1763-1771, 1989.

MALLANTS, D.; BINAYAK, P.M.; DIEDERIK, J.; FEYEN, J. Spatial variability of hydraulic properties in a multi-layered soil profile. Soil Science, v.161, p.167-181, 1996.

McBRATNEY, A.B.; WEBSTER, R. Choosing functions for semi-variograms of soil properties and fitting them to sampling estimates. Journal Soil Science, v.37, p.617-639, 1986.

NOVAES FILHO, J.P.; COUTO, E.G.; OLIVEIRA, V.A.; JOHNSON, M.S.; LEHMANN, J.; RIHA, S.S. Variabilidade especial de atributos físicos de solo usada na identificação de classes pedológicas de microbacias na Amazônia meridional. Revista Brasileira de Ciência do Solo, v.31, p.91-100, 2007.

PACHEPSKY, Y.A.; TIMLIN, D.J.; RAWLS, W.J. Soil water retention as related to topographic variables. Soil Science Society of America Journal, v.65, p.1787- 1795, 2001.

PAZ-GONZÁLEZ, A.; VIEIRA, S.R.; TABOADA CASTRO, M. The effect of cultivation on the variability of selected properties of an umbric horizon. Geoderma, v.97, p.273-292, 2000.

REZAEI, S. A.; GILKES, R. J. The effects of lanbulk densitycape attributes and plant community on soil physical properties in rangelanbulk density. Geoderma, v.125, p.145-154, 2005.

SILVA, M.B.; ANJOS, L.H.C.; PEREIRA, M.G.; NASCIMENTO, R.A.M. Estudo de toposseqüência da baixada litorânea fluminense: efeitos do material de origem e posição topográfica. Revista Brasileira de Ciência do Solo, v.25, p.965-976, 2001.

SOBIERAJ, J.A.; ELSENBEER, H.; COELHO, R.M.; NEWTON, B. Spatial variability of hydraulic contutivity along a tropical rainforest catena. Geoderma, v.108, p.79-90, 2002. 
SOIL SURVEY STAFF. Soil taxonomy: a basic system of soil classification for making and interpreting soil surveys 2 ed. Washington D.C.: USDA/NRCS, 1999, p.869 (Agricultural Handbook, 436)

SOUZA, C.K.; MARQUES JÚNIOR, J.; MARTINS FILHO, M.V.; PEREIRA, G.T. Influência do relevo na variação anisotrópica dos atributos químicos e granulométricos de um Latossolo em Jaboticabal - SP. Engenharia Agrícola, v.23, p.486-495, 2003.

SOUZA, Z.M.; MARQUES JÚNIOR, J.; PEREIRA G.T. Variabilidade espacial de atributos físicos do solo em diferentes formas do relevo sob cultivo de cana-de-açúcar. Revista Brasileira de Ciência do Solo, v.28, p.937-944, 2004.

TRANGMAR, B.B.; YOST, R.S.; UEHARA, G. Application of geostatistics to spatial studies of soil properties. Advances in Agronomy, v.38, p.45-93, 1985.

VAUCLIN, M.; VIEIRA, S.R.; VAUCHAUD, G.; NIELSEN, D.R. The use of cokringing with limited field soil observation. Soil Science Society of America Journal, v.47, p.175-184, 1983. VIEIRA, S.R.; HATFIELD, J.L.; NIELSEN, D.R.; BIGGAR, J.W. Geostatistical theory and application to variability of some agronomical properties. Hilgardia, v.51, p.1-75, 1983.
VIEIRA, S.R.; TILLOSTSON, P.M.; BIGGAR, J.W.; NIELSEN, D.R. The scalling of semivariograms and the kriging estimation. Revista Brasileira de Ciência do Solo, v.21, p.525-533, 1997.

VIEIRA, S.R. Geoestatística em estudos de variabilidade espacial de solos. In: Sociedade Brasileira de Ciência do Solo. Tópicos avançados em Ciência do Solo. Viçosa: SBCS, 2000. 53p.

WALKLEY, A.; BLACK, I.A. An examination of the Degtjareff method of determining soil organic matter and a proposed modification of the chromic acid titration method. Soil Science, v.37, p.29, 1934.

WEBSTER, R. Is soil variation random? Geoderma, v.97, p.149163,2000

WEBSTER, R. Statistics to support soil research and their presentation. European Journal of Soil Science, v.52, p.331$340,2001$.

Received May 25, 2007

Accepted August 29, 2008 